\title{
Transgenic rainbow trout expressed sGnRH-antisense RNA under the control of sGnRH promoter of Atlantic salmon
}

\section{S Uzbekova, J Chyb, F Ferrière ${ }^{1}$, T Bailhache ${ }^{1}$, P Prunet, P Alestrom ${ }^{2}$ and B Breton}

Station Commune de Recherches en Ichtyophysiologie, Biodiversité et Environment INRA, Campus de Beaulieu, 35042 Rennes, France

${ }^{1}$ UPRES-A CNRS 6026, Université de Rennes, France

${ }^{2}$ Norwegian School of Veterinary Science, Oslo, Norway

(Requests for offprints should be addressed to B Breton)

\begin{abstract}
A recombinant vector containing antisense DNA complementary to Atlantic salmon (Salmo salar) sGnRH cDNA driven by specific promoter Pab derived from a corresponding sGnRH gene was introduced into rainbow trout (Oncorhynchus mykiss) eggs. This resulted in transgenic animals that had integrated one copy of the transgene into their genome and transmitted it through the germline. Antisense-sGnRH mRNA (AS) was expressed mainly in the brain of transgenic $\mathrm{AS}(+)$ fish. Levels of sGnRH endogenous mRNA in the brain were lower in 11-month-old $\mathrm{AS}(+)$ fish compared with nontransgenic $\mathrm{AS}(-)$ individuals from the same F2 progeny. sGnRH levels significantly decreased in the pituitary of trans-
\end{abstract}

genic males and females around the maturation period and in the brain of $\mathrm{AS}(+)$ immature females compared with controls. No reliable statistical difference was found in the levels of FSH and $\mathrm{LH}$ between $\mathrm{AS}(+)$ and $\mathrm{AS}(-)$ groups either in immature or mature fish. The majority of transgenic fish reached maturity at the same time as did nontransgenic individuals, although the maturation of $\mathrm{AS}(+)$ animals seemed to be more asynchronous. For the first time, the influence of antisense messengers on endogenous mRNA in transgenic fish and the corresponding protein is described.

Fournal of Molecular Endocrinology (2000) 25, 337-350

\section{INTRODUCTION}

A certain number of farmed fish species such as salmon, common carp, tilapia, seabream and rainbow trout (Chen et al. 1996, Iyengar et al. 1996, Maclean 1998) are routinely used for gene transfer experiments. Besides the commonly used reporter genes lac $Z$, cat or $g f p$, several functional genes have been used to produce transgenic fish, such as the growth hormone $(\mathrm{GH})$ gene in salmon (Du et al. 1992, Devlin et al. 1994), carp (Chen et al. 1993) and tilapia (Martinez et al. 1996); and the antifreeze protein gene (AFP) in goldfish (Wang et al. 1995) and salmon (Hew et al. 1992). Expression of foreign genes may significantly change the physiological characteristics of transgenic fish (Mori \& Devlin 1999, Pitkanen et al. 1999). Although the majority of transgenic farmed fish have been raised indoors, escape remains possible and is considered as a risk to the environment. The goal of biosafety through biological containment may be achieved by means of induced sterility in transgenic fish lines.

It is known that hypogonadal mice, bearing a deletion in the GAP region of the gonadotropinreleasing hormone $(\mathrm{GnRH})$ gene, have infantile reproductive systems and levels of gonadotropins lower than normal, causing complete sterility in this line (Mason et al. 1986). In fish, as in other vertebrates, $\mathrm{GnRH}$ is the main neuromediator controlling the gonadotropic function of the brain-pituitary-gonadal axis (Breton et al. 1992). Two forms of this decapeptide have been identified in salmonids, the salmon GnRH (sGnRH) and the chicken GnRH-II (cGnRH-II), which are both 


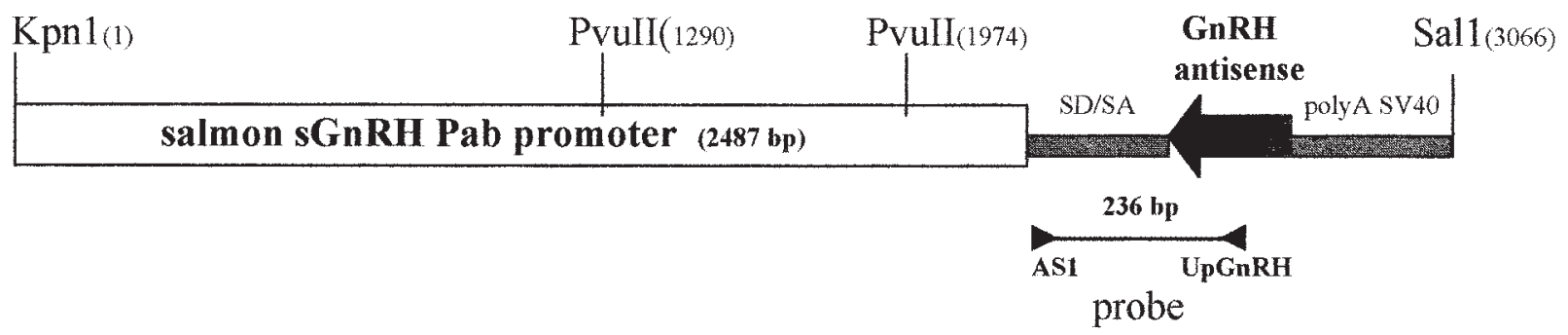

FIGURE 1. Schematic representation of Pab-sGnRH-antisense construct used to produce transgenic rainbow trout. Positions of restriction sites are in brackets. AS1 and UpGnRH are specific primers.

present in the brain and gonads of rainbow trout (Von Schalburg et al. 1999b). Salmon GnRH is considered to be the gonadotropin releaser and plays a key role in sexual maturation in salmonids (Breton et al. 1992). There are two different genes for $s \mathrm{GnRH}$ in rainbow trout: sGnRH gene-1 and gene- 2 encoding the same sGnRH peptide (Ferriere et al. 1999, Von Schalburg \& Sherwood 1999). We hypothesised that in vivo blocking of $\mathrm{sGnRH}$ production would probably induce sterility in fish, as it does in hypogonadal mice, and that gametogenesis in these former animals may be induced by a prolonged treatment with gonadotropins (Singh et al. 1995).

The partial inhibition of target gene expression, at either the mRNA or protein level, by complementary antisense mRNA in transgenic organisms has been shown in numer ous works (for reviews see: Sokol \& Murray 1996, Erikson 1999). However, in transgenic animals, the inhibitory effect of antisense RNA is seen to vary from complete failure (Munir et al. 1990) to a 50\% reduction in the level of target protein (Matsumoto et al. 1993, 1995). There are several mechanisms by which antisense RNA may exert its effects (Denhardt 1992), but the main inhibition of endogenous RNA is due to its destabilisation by antisense transcripts (Scherczinger et al. 1992, Jiang et al. 1994)

The objectives of the present study were to try to antagonise the in vivo production of sGnRH in a transgenic line of rainbow trout through the transfer of a sGnRH-antisense construction driven by a specific salmon sGnRH Pab promoter (Klungland et al. 1992b, Husebye et al. 1997). We hypothesised that antisense sGnRH mRNA transcripts may interact with prepro-sGnRH messengers and lead to a decrease in $\mathrm{sGnRH}$ production if the expression occurred in the sGnRH-producing cells. Inhibition of gametogenesis, if such an inhibition occurred, would be restored by injections of pituitary extracts as demonstrated in immature rainbow trout (Upadhyay 1977).

\section{MATERIALS AND METHODS}

\section{Animals}

Rainbow trout (Oncorhynchus mykiss) were obtained from the Drennec INRA fish farm (Sizun, France). Before handling, fish were deeply anaesthetised in fresh water with $0 \cdot 03 \%$ 2-phenoxy-ethanol. The eggs from newly ovulated females were fertilised and given microinjections of linear DNA fragment (see below). Transgenic fish and their progenies were maintained at $12{ }^{\circ} \mathrm{C}$ under artificial light-darkness conditions, mimicking the annual photoperiodic variations.

\section{The gene constructs}

The 'Pab-sGnRH-antisense' construct used in this study (H Husebye \& P Alestrom, unpublished data) contains a $2.5 \mathrm{~kb} \mathrm{sGnRH}$ Pab promoter (Klungland et al. 1992b), a $180 \mathrm{bp}$ fragment of the SV40 late $16 \mathrm{~s} / 19 \mathrm{~s}$ splice donor and an SD/SA acceptor signal (Okayama \& Berg 1992) fused to the inverted sGnRH cDNA $151 \mathrm{bp}$ fragment, containing the last $8 \mathrm{bp}$ of exon I, and the entire exon II (Klungland et al. 1992a), followed by the SV40 polyadenylation signal (Fig. 1). There are a total of $16 \mathrm{bp}$ mismatches between the sGnRH-antisense and trout sGnRH-I cDNA, and 4 bp mismatches between the sGnRH-antisense and trout sGnRH-II cDNA (Ferriere et al. 1999, Von Shalburg \& Sherwood 1999) (Fig. 2). The 'Pab-lacZ' construct (Husebye et al. 1997) had the same regulatory sequences as Pab-sGnRH-antisense, which surrounded $3 \cdot 5 \mathrm{~kb}$ of the LacZ coding sequence.

Plasmid DNA was digested with KpnI and SalI and fragments of approximately $3 \mathrm{~kb}$ for 


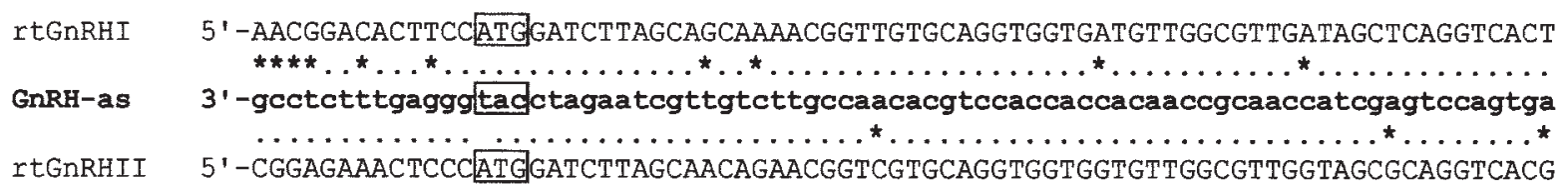

rtGnRHI TTCTCT CAGCATTGGTCGTATGGGTGGCTACCTGGAGGAAAGAGAAGTGTTGGGGAGCTGGAGGCCACCATCAGG -3 , GnRH-as gagagagtcgtgaccagcataccgaccgatggacctccttctcttcacatcecctcgacctcoggtggtagttc -5 .

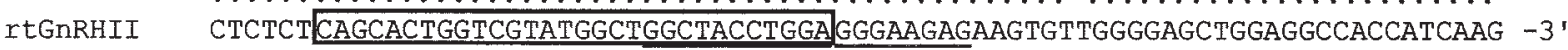

FIGURE 2. Comparative alignment of sGnRH-antisense transgene sequences written as complementary sequences in sense direction with rainbow trout (rt) sGnRH-I and sGnRH-II brain cDNA (Ferriere et al. 1999). Mismatches in the complementary sequences are indicated by stars. The UpGnRH primer is underlined. Start codon and sGnRH-decapeptide coding sequences are boxed.

Pab-sGnRH-antisense and $6 \cdot 3 \mathrm{~kb}$ for Pab-lacZ were recovered from the gel and purified prior to microinjection.

\section{Production of transgenic rainbow trout}

The linear DNA fragment was microinjected into freshly fertilised trout eggs (approximately $10^{6}$ copies per egg), using the two-step method developed by Chourrout et al. (1986). Microinjected eggs were incubated at $12{ }^{\circ} \mathrm{C}$.

Transgenic embryos raised from eggs microinjected with $\mathrm{Pab}-\mathrm{lac} Z$ construct were analysed for $\beta$-galactosidase $(\beta$-gal) expression at the age of 57 days postfertilisation. The Pab-lac $Z$ insert was detected by PCR with specific primers in the trunk of fish prior to immunostaining. Pab-lac Z stable transgenic lines were not produced.

Five-month-old fish raised from eggs microinjected with $\mathrm{Pab}-\mathrm{sGnRH}$-antisense construct were screened for the presence of transgenes by PCR. Fish containing the insert were kept. The sex of Pab-sGnRH-antisense immature fish was determined at 7-9 months by measurement of plasma concentrations of 11-ketotestosterone using RIA (Le Bail et al. 1983), as there are no phenotypic differences in the sexes before maturity in trout. Precocious spermatogenesis was induced in F0 (founder) and F1 males after repeated intraperitoneal injections of pituitary extract in $0.9 \% \mathrm{NaCl}$ (3 mg/kg body weight, twice a week) (Upadhyay 1977). Males carrying the transgene in sperm were crossed with wild-type females in order to produce following generations. Integration of a transgene insert into the genome was confirmed by Southernblot hybridisation on $\mathrm{F} 1$ fish and their $\mathrm{F} 2$ progenies. F2 Pab-sGnRH-antisense transgenic families were

www.endocrinology.org produced by mating the same wild type female with two F1 transgenic males with the identical transgene integration hybridisation pattern. Both families had the same genotype at the transgenic locus, and were thus considered to be identical transgenic lines.

\section{Extraction and analysis of DNA}

For rapid screening using PCR, genomic DNA was extracted according to Estoup et al. (1996) from small pieces of fin incubated for $1-3 \mathrm{~h}$ at $55^{\circ} \mathrm{C}$ in $0.5 \mathrm{ml} \mathrm{10 \%}$ Chelex100 resin (Biorad, Marne la Coquette, France) containing $250 \mu \mathrm{g} / \mathrm{ml}$ of proteinase $\mathrm{K}$. Proteinase $\mathrm{K}$ was then inactivated for $10 \mathrm{~min}$ at $95{ }^{\circ} \mathrm{C}$. Samples were centrifuged at $12000 \boldsymbol{g}$ for $1 \mathrm{~min}$. Two microlitres of each sample were amplified in $12.5 \mu \mathrm{l}$ standard PCR mix, using $125 \mathrm{nM}$ of specific primers for sGnRH-antisense and 0.65 unit AmpliTaq Perkin Elmer (Foster City, CA, USA) per reaction. Thirty five to forty PCR cycles were performed in a PTC-100 thermocycler (MJ Research Inc., Watertown, Massachussetts, USA), each cycle containing $30 \mathrm{~s}$ denaturation at $94{ }^{\circ} \mathrm{C}, 30 \mathrm{~s}$ annealing at $60{ }^{\circ} \mathrm{C}$ and $30 \mathrm{~s}$ amplification at $72{ }^{\circ} \mathrm{C}$.

For Southern-blot hybridisation, genomic DNA was extracted from $50 \mu \mathrm{l}$ blood or $200 \mathrm{mg}$ muscle lysed in $4 \mathrm{ml}$ TNES-urea buffer with $200 \mu \mathrm{g} / \mathrm{ml}$ of proteinase K (Tewari et al. 1992). DNA was extracted twice with phenol-chloroform, then ethanol precipitated and dissolved in sterile water. $10 \mu \mathrm{g}$ DNA were digested with restriction enzymes, run on a $0.9 \%$ agarose gel at $50 \mathrm{~V}$ for 20 to $24 \mathrm{~h}$ and then transferred onto HybondN ${ }^{+}$membranes according to the manufacturer's protocol (Amersham, Les Illes, France). Hybridisation with 
a ${ }^{32} \mathrm{P}$-labeled probe was performed for $16 \mathrm{~h}$ at $65^{\circ} \mathrm{C}$ in $0.5 \mathrm{M}$ phosphate buffer $\mathrm{pH} 7 \cdot 4,7 \% \mathrm{SDS}$ and $50 \mu \mathrm{g} / \mathrm{ml}$ calf thymus DNA. The membrane was washed in $2 \times \mathrm{SSC}, 0.5 \% \mathrm{SDS}$, then in $1 \times \mathrm{SSC}$, $0 \cdot 1 \% \mathrm{SDS}$, and twice in $0 \cdot 2 \times \mathrm{SSC}, 0 \cdot 1 \% \mathrm{SDS}$ at $60{ }^{\circ} \mathrm{C}$ and exposed on a Kodak film at $-80{ }^{\circ} \mathrm{C}$.

\section{RNA preparation and analysis}

Total RNA was prepared from brains and other tissues of individual fish using the 'RNA-Insta-Pure' extraction kit (Eurogentec, Angeres, France) or total RNA isolation reagent (Trisol, Gibco, Gaithersburg, USA). When 60- and 90-day-old fish were analysed, RNA was extracted individually from the whole heads. DNAse treatment of total RNA was performed using 1 unit RQ1-DNAse (Promega, Charbonnierès, France) per $1 \mu \mathrm{g}$ RNA at $37^{\circ} \mathrm{C}$ for $15 \mathrm{~min}$. RNA was re-extracted with phenol-chloroform, ethanol precipitated and dissolved in sterile water. Total RNA $(0 \cdot 5-2 \mu \mathrm{g})$ was reverse transcribed with oligo-dT primer and 200 units MMLV-Reverse-Transcriptase per reaction according to the manufacturer's protocol (Gibco). Template cDNAs were amplified using 2.5 units Taq DNA-polymerase (Perkin Elmer applied system) and $500 \mathrm{nM}$ primers specific for rainbow trout $\beta$-actin, sGnRH-I, sGnRH-II and sGnRHantisense mRNA in a final volume of $50 \mu \mathrm{l}$, containing $1 \times \mathrm{PCR}$ buffer $(\mathrm{PE}), 1.5 \mathrm{mM} \mathrm{MgCl}_{2}$ and $200 \mu \mathrm{M}$ dNTPs.

\section{Development of a semi-quantitative RT-PCR analysis}

Determination of the linear range of amplification was performed experimentally by varying the number of cycles and the quantity of RNA taken for reverse transcription. PCR conditions were as follows: after an initial denaturing step at $94{ }^{\circ} \mathrm{C}$ for $3 \mathrm{~min}$, the subsequent cycles consisted of denaturation at $94{ }^{\circ} \mathrm{C}$ for $30 \mathrm{~s}$, annealing at $61{ }^{\circ} \mathrm{C}$ for $30 \mathrm{~s}$ and elongation at $72{ }^{\circ} \mathrm{C}$ for $30 \mathrm{~s}$, for a number of cycles determined experimentally in order to be in the linear range of amplification for each gene of interest. The final incubation was performed at $72{ }^{\circ} \mathrm{C}$ for $10 \mathrm{~min}$. Each PCR reaction mixture was subjected to electrophoresis in $2.5 \%(\mathrm{w} / \mathrm{v})$ agarose gel stained with ethidium bromide and photographed under UV illumination with an image analysis system (Gel-Doc1000, Bio-Rad). The relative concentration of DNA was determined using the Molecular Analyst/PC software (Bio$\mathrm{Rad}$ ). and expressed as ratios of the gene specific signal (sGnRH-I or sGnRH-II) versus the $\beta$-actin standard.

\section{Primers used in RT-PCR analysis:}

rainbow trout $\beta$-actin (319 bp fragment amplified):

5'-AAAGACCCTGAGTTCATCATGC

5'-ACCCTAATCACCTCTGACCC

rainbow trout sGnRH-I (189 bp product amplified):

5'-TCAGGTCACTTTCTCTCAGCA

5'-TCTGGCATTCGTTTCTTCGAG

rainbow trout sGnRH-II (193 bp product amplified):

5'-GGTAGCGCAGGTCACGC

5'-GGGGCATCCATTTCTTCAAT

sGnRH-antisense (236 bp product amplified):

5'-TGCTCGAGGAACTGAAAAACC-3'

5'-GGCTACCTGGAGGGAAGAG-3'

lacZ (765 bp product amplified):

5'-TTTGATGGCGTTAACTCGGCG

5'-AGCGGATGGTTCGGATAATGC

\section{Northern blot}

PolyA mRNA was prepared by using the polyATtract mRNA isolation system III (Promega). Six brains from 11-month-old fish were pooled in each group. mRNA $(5 \mu \mathrm{g})$ was size fractionated in a $1 \%$ agarose-formaldehyde gel and transferred to Hybond $\mathrm{N}^{+}$membrane as described by the manufacturer's protocol (Amersham). Hybridisation with ${ }^{32} \mathrm{P}$-labelled sGnRH-antisense and $\beta$-actin DNA probes was performed as described above.

\section{Immunocytochemistry}

Embryos obtained from eggs microinjected with Pab-lacZ DNA were collected 57 days postfertilisation. The trunks were used to extract the genomic DNA and the heads were fixed in $0.1 \mathrm{M}$ phosphate buffer (PB) $\mathrm{pH} 7 \cdot 4$ with $4 \%$ paraformaldehyde for $12 \mathrm{~h}$ at $4{ }^{\circ} \mathrm{C}$, washed 3 times with $\mathrm{PB}$, then incubated for $12 \mathrm{~h}$ in $\mathrm{PB}$ with $20 \%$ sucrose. Samples were embedded in O.C.T. compound (Miles, Elkhart, IN, USA), frozen at $20^{\circ} \mathrm{C}$ and cut into $20 \mu \mathrm{m}$ serial sections. Sections were maintained on TESPA-treated slides and washed twice in PBS $\mathrm{pH} 7 \cdot 4$. Double immuno-staining was performed by incubating the slides overnight with specific $\mathrm{GnRH}$-antiserum (rabbit anti-sGnRH at a dilution of $1 / 200)$ and anti- $\beta$-galactosidase monoclonal antibodies (at a dilution of $1 / 500$, Promega) in PBS containing $0 \cdot 1 \%$ Triton $\mathrm{X} 1100$ at $4{ }^{\circ} \mathrm{C}$. Sheep anti-mouse FITC-conjugated antibodies (Sigma) were used for $\beta$-galactosidase detection and donkeyanti-rabbit TRITC-conjugated antibodies (Jackson) were used to visualise GnRH-producing cells. Sections were observed using a fluorescent microscope equipped with the appropriate filters. 


\section{GnRH}

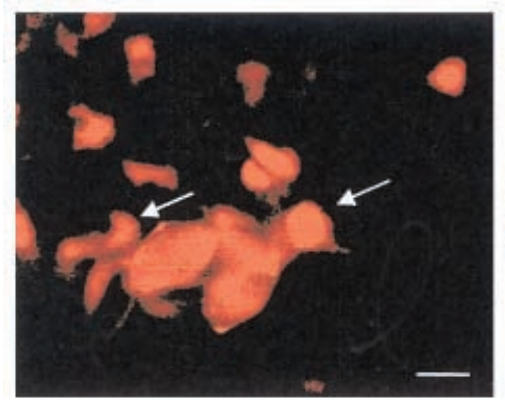

$\beta$-gal

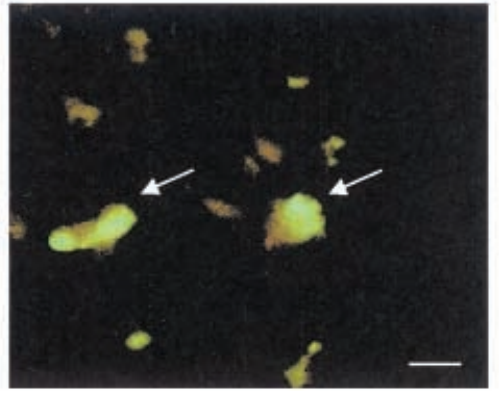

FIgURE 3. GnRH and $\beta$-gal expression in Pab-lac $Z$ transgenic rainbow trout: $\mathrm{GnRH}$ and $\beta$-gal immunoreactive cells in the ganglion of the cribriform bone $(\mathrm{gCB})$ in 57-day-old transgenic fish. Double immunostaining was performed on the same section. Arrows indicate cells in which GnRH (red fluorescence) and $\beta$-gal (green fluorescence) are colocalised. Bar represents $10 \mu \mathrm{m}$.

\section{Determination of $\mathbf{s G n R H}$ concentrations in brain and pituitary}

Extraction of GnRH from pituitaries and brains was performed according to Kah et al. (1994). In juvenile fish (60- and 90-days-old), GnRH was extracted from the whole skulls of 16 fish from each family. Tissues from each fish were homogenised in $2 \mathrm{M}$ acetic acid, sonicated for $30 \mathrm{~s}$ on ice, then heated for $10 \mathrm{~min}$ at $80^{\circ} \mathrm{C}$. The samples were then centrifuged for $20 \mathrm{~min}$ at $12000 \mathrm{~g}$. The supernatants were lyophilised and reconstituted in BSAfree EIA-buffer $(250 \mu \mathrm{l}$ for one pituitary and $2 \mathrm{ml}$ for one brain) and subjected to ELISA as described by Kah et al. (1994). The specific sGnRH antiserum was used at a 1:20000 dilution, and the conjugated sGnRH-acetylcholinesterase (Spibio, Massy, France) was used as a tracer.

\section{FSH and LH measurements}

Blood was sampled from a caudal vessel and plasma was separated by centrifugation at $2000 \boldsymbol{g}$ for $10 \mathrm{~min}$ and kept frozen until assayed. Levels of gonadotropins, Luteinizing hormone (LH) and follicle stimulating hormone (FSH), were measured in $50 \mu \mathrm{l}$ plasma using specific radioimmunoassays (Govoroun et al. 1998).

\section{Protein assays}

Pituitary and brain extracts (in BSA-free EIAbuffer) were analysed for protein content using the BCA protein assay kit (PIERCE, Rockford, IL, USA).

www.endocrinology.org

\section{Statistical analyses}

Data are expressed as means \pm s.E.M. Results were analysed using Student's $t$-test. The differences were considered significant at $P<0 \cdot 05$.

\section{RESULTS}

\section{Expression of lacZ driven by Pab-promoter in F0 transgenic rainbow trout}

In order to prove that the tissue-specific expression was directed by the Pab-promoter, we analysed several juvenile fish, obtained from eggs microinjected with Pab-lacZ fragment, at 57 days post-fertilization. It was assumed that the GnRHimmunoreactive (GnRH-ir) cells that express $\beta$-gal would be observable even though there are only several dozen sGnRH neurones in the trout brain at this stage of development. As was expected, a few cells were $\beta$-gal positive in fish showing the presence of the lac $Z$ transgene in their genomic DNA by PCR analysis, but no such cells were observed in control animals. By doubleimmunochemistry, the colocalisation of s GnRH and $\beta$-galactosidase was detected in 57-day-old fish in the same cells of the ganglion of the cribriform bone ( $\mathrm{gCB}$ ), where most of the GnRH-ir neurones were concentrated at this stage of development (Fig. 3).

\section{Generation of a rainbow trout Pab-sGnRH-antisense transgenic line}

F2 Pab-sGnRH-antisense transgenic families were produced as described in Fig. 4. Briefly, the 
Dec 1995

F0

F1

\section{Microinjection}

of Pab-sGnRH-antisense transgene

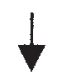

$20 \mathrm{AS}(+)$ out of 56 fish

AS $(+)$ fish: 5 males and 15 females

Nov 1996

Apr 1998

F2

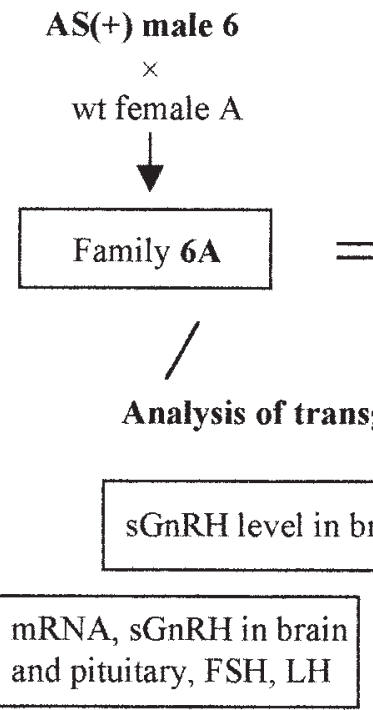

June 1998

July 1998

Mar 1999

Aug 1999

Dec 1999
AS(+) male $3 \times$ wild type female

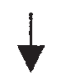

$30 \mathrm{AS}(+)$ out of $286 \mathrm{fish}$
Transgene was detected in at least one tissue

Transgene was detected in sperm also
Transgene integration locus was the same in both males

wt female A

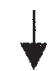

Family 15A

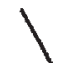

$50 \%$ of progeny were $\mathrm{AS}(+)$ 60-days-old

90-days-old

11-months-old

15-months-old

20-months-old

FIGURE 4. Production and analysis of 'Pab-sGnRH-antisense' rainbow trout populations: time schedule schematic presentation. F0 fish were often mosaic, they were considered as transgenic $(\operatorname{AS}(+))$ if transgene was detected in at least one tissue. Only one F0 male (male 3) retained the sGnRH-antisense transgene in its sperm, and it became a founder for the F1 generation. The same wild type (wt) female A was crossed with F1 brothers 6 and 15, identical at transgenic locus. Juveniles from both F2 families were analysed at 60- and 90-days-old for sGnRH levels in the brain. About 160 fish from F2 family 6A were analysed at 11-months-old for several parameters. Forty $\mathrm{AS}(+)$ and 52 non transgenic $(\operatorname{AS}(-))$ males from F2 family 15A were analysed at 15-months-old for spermiation. Sixteen AS $(+)$ and $14 \mathrm{AS}(-)$ females from F2 family $15 \mathrm{~A}$ were analysed for several physiological parameters at 20 months of age.

microinjection of Pab-sGnRH-antisense DNA fragment into rainbow trout eggs was performed in December 1995. In June 1996, DNA samples from the blood and fins of 56 fish were analysed for the presence of the transgene. After PCR analysis, 15 females and 5 males proved to be positive for the transgene in at least one tissue. Following hormonal induction of precocious spermatogenesis beginning 


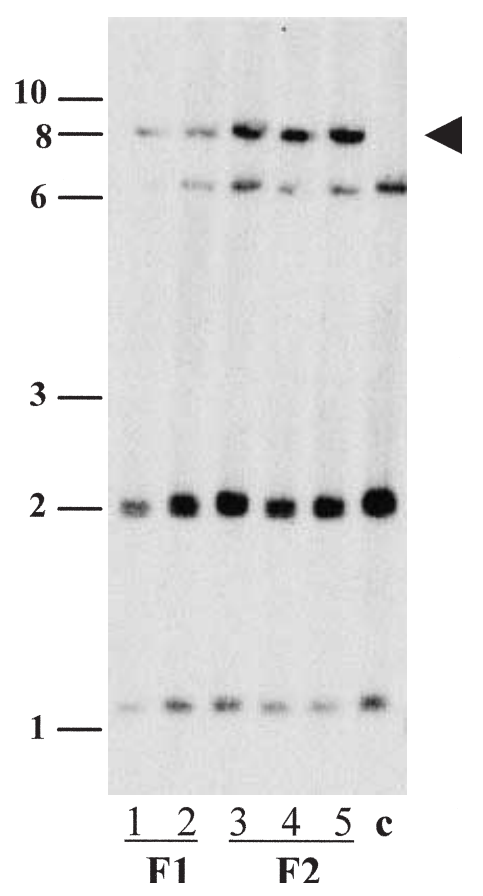

FIGURE 5. Southern-blot hybridisation of genomic DNA of Pab-sGnRH-antisense transgenic fish with 'AS1-UpGnRH' 236 bp fragment as a probe.

PvuII-digested DNA (10 $\mu \mathrm{g})$ was loaded per line. Lanes 1-2: F1 founders 6 and 15; lanes 3-5: individual fish from 6A family; lane c: control nontransgenic fish. Transgene is marked by the arrowhead.

in September 1996, one male was found to carry the gene of interest in its sperm. It was crossed with a wild type female in November 1996.

Ten point five per cent of progeny were found to possess the transgene ( 30 positive fish of the 286 analysed). This confirmed the mosaic integration of introduced construct in F0 founder. Two groups of 25 F1 off-spring issued from the same F1 family, one positive, retaining the transgene (group $\mathrm{AS}(+)$ ), the other one, negative, not retaining the transgene (group $\mathrm{AS}(-)$ ) were reared in the same tank. There were 19 females and 6 males among the positive fish and 14 females and 11 males in the negative group. Four out of six $\mathrm{AS}(+)$ males started natural spermiation in November 1997, whereas all negative males did so. The $2 \mathrm{AS}(+) \mathrm{F} 1$ nonspermiating males were still nonspermiating 1.5 months later. They finally started spermiation after a 1 week treatment with pituitary extract (mid-January 1998). Two F2 Pab-sGnRH-antisense families, 6A and 15A, were produced in April 1998 by crossing these males with the same wild type female. Both F1 founders had the same transgene integration locus which was characterised by an identical hybridisation pattern

www.endocrinology.org

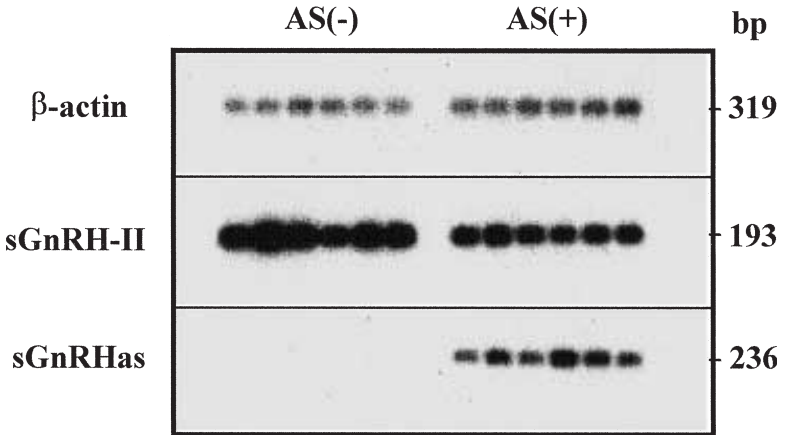

FIGURE 6. Detection of sGnRH-antisense, sGnRH-II and $\beta$-actin transcripts in brains of 11 -month-old transgenic Pab-sGnRH-antisense F2 individuals by RT-PCR. Total RNA $(1 \mu \mathrm{g})$ was converted to cDNA; $0 \cdot 1$ part of cDNA was subjected to 27 PCR cycles with specific primers for sGnRH-II and $\beta$-actin and to 35 cycles for sGnRH-antisense. The PCR products were visualised by Southern-blot hybridisation with sGnRH and $\beta$-actin DNA probes.

transmitted without modification to their F2 progenies (Fig. 5). Both F2 families showed a transgene incidence close to $50 \%$ with a frequency of $51 \cdot 8 \%$ in the $6 \mathrm{~A}$ family $(114 / 220)$ and $52 \cdot 2 \%$ in the 15A family (92/176). Taken together, these results allowed us to consider the $6 \mathrm{~A}$ and $15 \mathrm{~A} \mathrm{~F} 2$ transgenic families to be heterozygous, stable lines identical at the Pab-sGnRH-antisense transgene locus.

\section{Analysis of sGnRH-antisense transgene expression}

Antisense sGnRH RNA was detected using the high-sensitivity RT-PCR method. Using specific primers for sGnRH-antisense (Fig. 1), a fragment of expected size $(236 \mathrm{bp})$ was amplified only in $\mathrm{AS}(+)$ individuals of both sexes at 11 months of age, while the presence of $\beta$-actin and sGnRH messengers were detected in all examined fish (Fig. 6). Expression of sGnRH-antisense was also detected in the brain of all transgenic fish analysed at 60 and 90 days post-fertilisation (data not shown).

Northern-blot hybridisation of brain mRNA with sGnRH-antisense cDNA as a probe revealed an approximately $650 \mathrm{bp}$ long transcript which corresponds to host sGnRH mRNA in the two groups. In $\mathrm{AS}(+)$ samples, a smear band of higher molecular weight was detected that might be sGnRHantisense RNA (Fig. 7). A detailed analysis of GnRH-antisense expression in tissues other than brain was not carried out in transgenic fish, but from RT-PCR analysis we detected sGnRHantisense transcripts in the gonads and gills, but not 


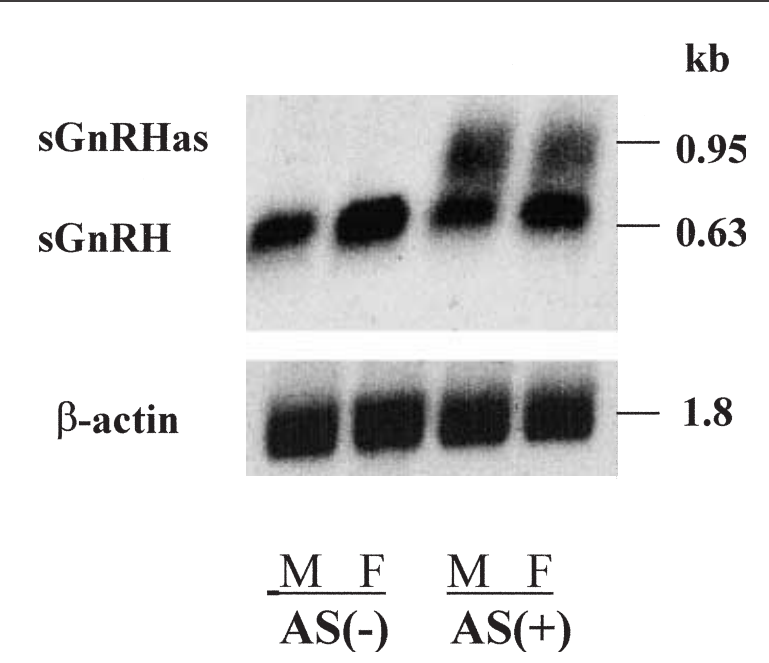

FIGURE 7. Northern-blot hybridisation of mRNA from the brain of 11-month-old transgenic Pab-sGnRHantisense F2 males (M) and females (F). PolyA mRNA $(5 \mu \mathrm{g})$ was loaded per line. Hybridisation with sGnRH-antisense (236 bp fragment) and $\beta$-actin DNA probes was performed.

in the muscles, pituitary, kidney or intestine of individual immature $\mathrm{AS}(+)$ fish (Fig. 8).

Expression of sGnRH-I and sGnRH-II mRNA in the brain of transgenic and nontransgenic fish was compared using a RT-PCR technique, thus allowing the semi-quantitative determination of their relative abundance in correlation with $\beta$-actin mRNA expression. The linear range of the reaction was defined as being the PCR period during which amplification efficiency was at its maximum and remained constant over a number of cycles. To obtain meaningful results, the relative RT-PCR reaction had to be terminated and the products quantified when all the reactions were in the linear range of amplification. Experiments were performed to determine the number of cycles which produced quantifiable signals within a linear range of amplification. Figure 9 shows that the linear range of amplification was obtained between cycles 26 and 32, for all amplified products. Moreover, all PCR

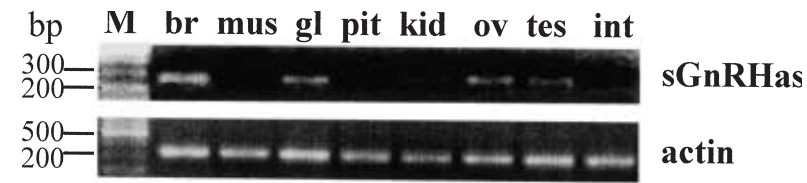

FIGURE 8. RT-PCR analysis of sGnRH-antisense expression in different tissues of Pab-sGnRH-antisense transgenic fish. Forty PCR cycles using specific primers were performed using $1 \mu \mathrm{g}$ transcribed DNAase-treated RNA. br, brain; mus, muscle; gl, gills; pit, pituitary; kid, kidney; ov, ovary; tes, testis; int, intestine.
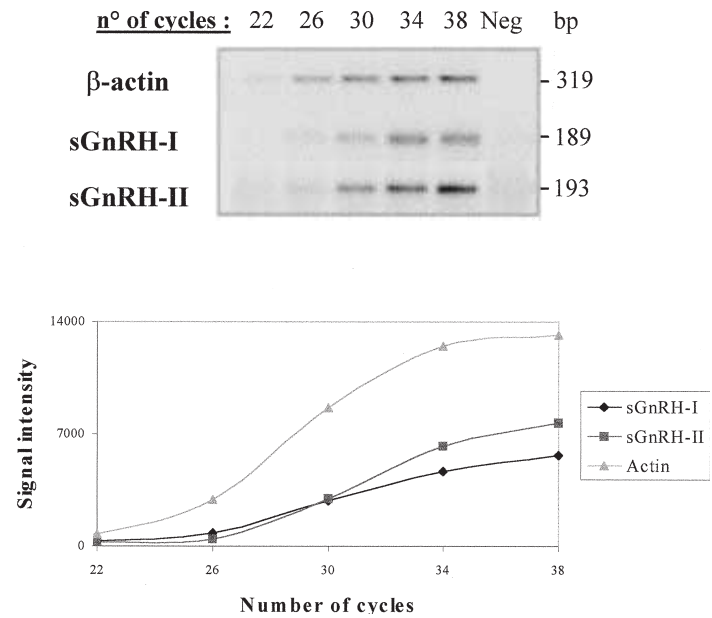

FIGURE 9. Establishment of relative RT-PCR analysis. Determination of the linear range of amplification of sGnRH-I, sGnRH-II and $\beta$-actin cDNA. Total RNA $(0 \cdot 5 \mu \mathrm{g})$ from the forebrain of vitellogenic rainbow trout was used for reverse transcription with oligo-dT primers. cDNA was then amplified as described in Materials and Methods and PCR products were subjected to electrophoresis and subsequently quantified.

reactions remained in the linear range between cycles 24 and 28, even if the RNA concentration for $\mathrm{RT}$ reactions increased (data not shown). Twentyseven cycles of PCR were carried out using $1 \mu \mathrm{g}$ transcribed RNA in the subsequent analysis.

There was a decrease in the $s \mathrm{GnRH} / \beta$-actin mRNA ratio in 11-month-old $\mathrm{F} 2 \mathrm{AS}(+)$ groups. However, this ratio was significantly lower only in $\mathrm{AS}(+)$ females for sGnRH-I mRNA, and in $\mathrm{AS}(+)$ males for sGnRH-II messengers (Fig. 10).

\section{Physiological studies}

$\mathrm{AS}(+)$ and $\mathrm{AS}(-)$ groups of $\mathrm{F} 2$ fish were compared for endocrinological parameters in relation to the gonadotropic function of the brain-pituitary complex (GnRH, LH and FSH).

\section{Brain and pituitary sGnRH}

Brain and pituitary sGnRH contents were measured in 60- and 90-day-old fish in both 6A and 15A F2 transgenic families that showed no difference in weight or size of juveniles. There was a nonsignificant difference in sGnRH brain and pituitary content between transgenic and non transgenic fish. The mean sGnRH content in the brain and pituitary of 60 -day-old $\mathrm{AS}(+)$ fish was $359 \pm 98 \mathrm{pg} /$ animal versus $430 \pm 87 \mathrm{pg} /$ animal in $\operatorname{AS}(-)$ individuals. In 90-day-old fish, the brain and pituitary content of $\mathrm{AS}(+)$ fish was $1153 \pm 89 \mathrm{pg}$ sGnRH per fish versus $1085 \pm 104 \mathrm{pg}$ in $\mathrm{AS}(-)$ fish. 


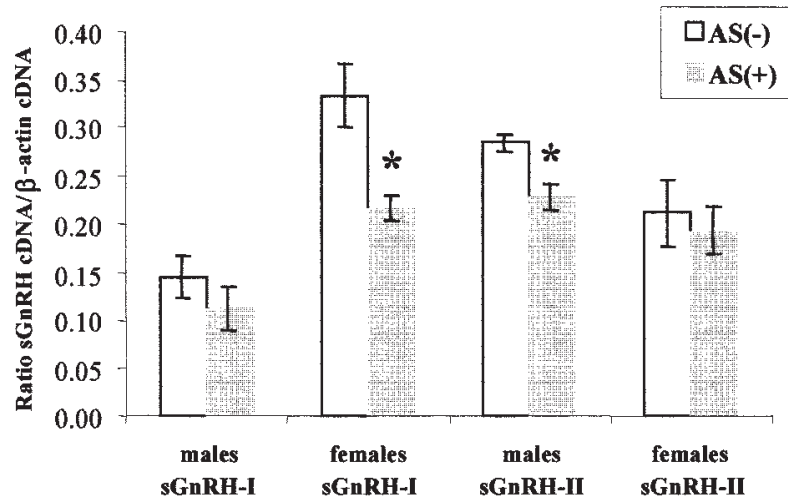

FIGURE 10. Expression of sGnRH-I and sGnRH-II mRNA in the brain of 11 -month-old Pab-sGnRHantisense transgenic rainbow trout. Six individual fish were analysed in each group. Total RNA $(0 \cdot 5 \mu \mathrm{g})$ was reverse transcribed followed by 27 PCR cycles. The ratio of optical density absorbency of amplified sGnRH-I and -II to $\beta$-actin products was calculated. * The differences were considered significant at $P>0.05$.

Later, $\mathrm{AS}(+)$ and $\mathrm{AS}(-)$ 11-month-old males and females from the 6A family (about 80 individuals in each group) were compared. Pituitary sGnRH content decreased significantly in $\mathrm{AS}(+)$ males, but not in females (Table 1). Conversely, the sGnRH concentration in the brain was significantly lower in $\mathrm{AS}(+)$ females, but not in $\mathrm{AS}(+)$ males. The same results were observed in F1 immature $\mathrm{AS}(+)$ females (data not shown). Further analysis of sGnRH levels in vitellogenic 20-month-old females from the 15A family showed a significant decrease in the sGnRH pituitary concentration in both $\mathrm{AS}(+)$ fish and mature 11-month-old AS (+) males (Table 1).

\section{Plasma FSH and LH}

Mean plasma levels of FSH were not significantly different between the $\mathrm{AS}(+)$ and $\mathrm{AS}(-)$ groups, regardless of the age of the fish (Table 1). LH plasma levels did not significantly decrease in $\mathrm{AS}(+)$ fish (Table 1), although there was a great variability between individual $\mathrm{AS}(+)$ females. $\mathrm{LH}$ levels ranged from a minimal value of $1.2 \mathrm{ng} / \mathrm{ml}$ to a maximal value of $30.9 \mathrm{ng} / \mathrm{ml}$. Values were more homogenous in $\operatorname{AS}(-)$ fish, with concentrations ranging from $1 \cdot 1 \mathrm{ng} / \mathrm{ml}$ to a maximum of $5.12 \mathrm{ng} /$ $\mathrm{ml}$.

\section{Gonadal development and maturation}

No significant difference was found either in mean body weight or gonado-somatic index (GSI) between $\mathrm{AS}(+)$ and $\mathrm{AS}(-)$ groups in 11-month-old fish (Table 1). The sex ratio was also comparable. In both 11-month-old groups there was a high variability in maturation stages among males, ranging from stage I (only spermatogonia are present) up to stage $\mathrm{V}$ (spermatozoa are already formed). At 15 months of age, the majority of males were already sexually mature. Among the $40 \mathrm{AS}(+)$ males, 31 spermiated $(77 \cdot 5 \%)$, and 41 out of the 52 males gave sperm simultaneously in the $\mathrm{AS}(-)$ group $(78 \cdot 8 \%)$. At the same age, females remained immature or were just beginning vitellogenesis $(\mathrm{GSI}<0 \cdot 5)$. Maturation of females from this family was further analysed when they reached 20 months of age in December 1999. The mean GSI was significantly lower in $\mathrm{AS}(+)$ females, being in the order of $5 \cdot 99 \pm 1 \cdot 34 \%$ (minimal and maximal values being $0.05 \%$ and $14.97 \%$ respectively) than in $\mathrm{AS}(-)$ females, for which the mean GSI was $10.02 \pm 0.99 \%$ (minimum and maximum values being $7 \cdot 03 \%$ and $15 \cdot 74 \%$ respectively). In $\mathrm{AS}(+)$ females, all stages of maturation from immature to ovulation were found, whereas $\operatorname{AS}(-)$ females were more synchronous, all fish being vitellogenic.

In summary, physiological studies revealed that: (1) sGnRH levels significantly decreased in the pituitary of transgenic males and females around the maturation period.

(2) LH and FSH levels were not significantly different between transgenic and non transgenic fish, regardless of sex and stage of maturity, although there was a greater variability among positive fish.

(3) There was no difference in the percentage of spermiating males in either group at 15 months.

(4) There was a high variability in the maturation stages (from immature to ovulated) of $\mathrm{AS}(+)$ females at 20 months, all $\mathrm{AS}(-)$ being fully vitellogenic animals.

\section{DISCUSSION}

\section{Pab-directed expression of inserted genes in transgenic trout}

Fused $\mathrm{Pa}$ and $\mathrm{Pb}$ promoter regions $(\mathrm{Pab})$ from the sGnRH gene of Atlantic salmon (Klungland et al. 1992a) used in this study conveyed specific expression in sGnRH producing cells. It has already been shown that this promoter directs the specific transient expression of lac $Z$ in neurone-like cells in the anterior forebrain of zebrafish embryos (Husebye et al. 1997). We showed that the same construct microinjected into rainbow trout eggs gave a weak but specific expression in GnRH-ir cells in $\mathrm{gCB}$ of transgenic fish 57 days postfertilisation. At this stage of salmonid development, 
TABLE 1. Comparative physiological analysis of transgenic $\mathrm{AS}(+)$ and nontransgenic $\mathrm{AS}(-)$ fish from 'Pab-sGnRH-antisense' F2 transgenic families

\begin{tabular}{|c|c|c|c|c|c|c|}
\hline & \multicolumn{2}{|c|}{ Males 11-months-old } & \multicolumn{2}{|c|}{ Females 11-months-old } & \multicolumn{2}{|c|}{ Females 20 -months-old } \\
\hline & $\mathrm{AS}(-)(n=43)$ & $\operatorname{AS}(+)(n=39)$ & $(\mathrm{AS}(-)(n=34)$ & $\mathrm{AS}(+)(n=41)$ & $\operatorname{AS}(-)(n=14)$ & $\mathrm{AS}(+)(n=16)$ \\
\hline \multicolumn{7}{|l|}{ Parameters } \\
\hline Weight (g) & $187 \pm 33$ & $180 \pm 27$ & $162 \pm 31$ & $165 \pm 39$ & $1096 \pm 56$ & $905 \pm 49$ \\
\hline $\operatorname{GSI}(\%)$ & $0 \cdot 28 \pm 0 \cdot 27$ & $0 \cdot 25 \pm 0 \cdot 20$ & $0 \cdot 13 \pm 0 \cdot 02$ & $0 \cdot 13 \pm 0 \cdot 03$ & $10 \cdot 02 \pm 0.99$ & $5 \cdot 99 \pm 1 \cdot 34$ \\
\hline $\begin{array}{l}\text { sGnRH in brain } \\
(\mathrm{pg} / \mu \mathrm{g} \text { protein })\end{array}$ & $2 \cdot 36 \pm 1 \cdot 59$ & $2 \cdot 60 \pm 1 \cdot 89$ & $3 \cdot 30 \pm 0 \cdot 21$ & $2 \cdot 54 \pm 1 \cdot 25$ & $6 \cdot 87 \pm 0 \cdot 53$ & $7 \cdot 43 \pm 0 \cdot 75$ \\
\hline $\begin{array}{l}\text { sGnRH in pituitary } \\
\text { (pg/pituitary) }\end{array}$ & $416 \cdot 3 \pm 35 \cdot 2$ & $271 \pm 24 \cdot 9$ & $298 \cdot 3 \pm 33 \cdot 9$ & $257 \pm 17 \cdot 4$ & $3112 \pm 379$ & $2223 \pm 247$ \\
\hline $\begin{array}{l}\text { FSH, plasma level } \\
(\mathrm{ng} / \mathrm{ml})\end{array}$ & $3 \cdot 08 \pm 0 \cdot 31$ & $2 \cdot 99 \pm 0 \cdot 32$ & $3 \cdot 11 \pm 0 \cdot 50$ & $3 \cdot 73 \pm 1 \cdot 10$ & $7 \cdot 38 \pm 1 \cdot 51$ & $8 \cdot 48 \pm 1 \cdot 74$ \\
\hline $\begin{array}{l}\mathrm{LH}, \text { plasma level } \\
\quad(\mathrm{ng} / \mathrm{ml})\end{array}$ & $0 \cdot 48 \pm 0 \cdot 17$ & $0 \cdot 41 \pm 0 \cdot 18$ & $0 \cdot 33 \pm 0 \cdot 03$ & $0 \cdot 35 \pm 0 \cdot 03$ & $2 \cdot 68 \pm 0 \cdot 31$ & $5 \cdot 26 \pm 2 \cdot 28$ \\
\hline
\end{tabular}

Values considered to be significantly different $(P<0 \cdot 05)$ are in bold.

the GnRH-expressing cells (about 100 per brain) are mainly concentrated in a relatively limited area including olfactory placode, $\mathrm{gCB}$ and rostral olfactory bulbs prior to their migration throughout the brain (Parhar et al. 1995, authors' unpublished observations). During ontogenesis, the functionality of GnRH-expressing neurones does not change, thus the expression of marker genes in sGnRH-ir cells of juvenile fish allowed us to conclude that the salmon Pab-promoter in rainbow trout was functional. The fact that few cells, and not in all transgenic animals, were found to express $\beta$-galactosidase may be due to the mozaicism of $\mathrm{F} 0$ transgenics (not all the cells retained the transgene in F0 fish), as well as to the effect of variegation of lac $Z$ expression, a phenomenon that has already been described in detail in the F2 lines of transgenic trout (Amoros 1998). These last transgenic fish expressed $\beta$-galactosidase driven by the $2.4 \mathrm{~kb}$ promoter of the salmon prolactin (PRL) gene only in PRL-producing cells of the pituitary. Expression of lac $Z$ varied significantly between individuals of the same progeny but also between the PRLexpressing cells of the same pituitary. Not all of the cells that should normally express lac $Z$ were observed to do so. In the present study, the salmon Pab-promoter may similarly not have targeted all the sGnRH-expressing cells, and this may also explain the mosaicism of transgene expression.

In Pab-sGnRH-antisense F2 transgenic fish, transgene expression was detected at different stages, beginning in 60-day-old fish. The fact that expression of sGnRH-antisense RNA was observed in $\mathrm{AS}(+)$ fish up to $\mathrm{F} 2$ progeny demonstrates that the Pab-sGnRH-antisense transgene is functional and integrated into active chromatin in a stable manner. It was transmitted without modification through the germ line. The transgene integration pattern analysed by Southern-blot hybridisation revealed the presence of a single copy of PabsGnRH-antisense DNA fragment in the transgenic lines (Fig. 4). There was only one additive band appearing in transgenic DNA compared with controls. Its size (approximately $8 \mathrm{~kb}$ ) did not correspond to those of several copies integrated into concatameres. The other bands that hybridised with the same probe (sGnRH-antisense DNA) corresponded to endogenous sGnRH genes and could be a reference for estimating the number of integrated copies of sGnRH-antisense transgene. The mendelian ratio of transgene transmission:non transmission in F2 (about 1:1) also supported a single integration site.

Expression of Pab-sGnRH-antisense construct was found to occur in greater amounts and with greater regularity in the brains of $\mathrm{AS}(+)$ fish, although expression was also detected in other tissues. The Atlantic salmon Pab-promoter used in this study had a high degree of homology with the rainbow trout sGnRH-II gene promoter, especially in its downstream region (Von Schalburg \& Sherwood 1999). However, this promoter fragment lacks several regulatory sequences present in trout sGnRH-1 and sGnRH-2 genes. The sGnRH gene-2 is found expressed in the ovary and testis in salmonids (Von Schalburg \& Sherwood 1999, Von Schalburg et al. 1999a). The presence of GnRH transcripts in tissues other than the brain and gonads have also been shown to occur in mammals (Maier et al. 1992, Kottler 1997) and Cichlidae (White \& Fernald 1998). Thus, the expression of 
transgenes driven by Pab promoters could potentially be detected in tissues other than the brain. The possibility of a rearrangement of the transgene flanking ends due to integration events cannot be excluded. Position effect itself may also influence expression. These factors, in addition to the relatively short size of the salmon Pab-promoter, can lead to an aberrant expression of the transgene in other tissues of transgenic trout, as was detected in our study.

More than $30 \mathrm{PCR}$ cycles were needed to visualise the amplified band of GnRH-antisense cDNA in brain by ethidium bromide staining. The amplification was linear up to 42 cycles (data not shown), whereas only $27 \mathrm{PCR}$ cycles were necessary to visualise the amplified bands of sGnRH-I and -II cDNA in the linear zone of the reaction. These data indirectly indicate that antisense RNA expression was less abundant than was endogenous sGnRH mRNA. In order to directly visualise the sGnRH sense and antisense transcripts in the brain of transgenic fish, Northern-blot analysis was performed. The DNA probe which was used for hybridisation (AS1-UpGnRH $236 \mathrm{bp}$ fragment) detected both transgenic antisense and endogenous sGnRH transcripts with a better specificity for $\mathrm{sGnRH}$-antisense (100\% homology, $236 \mathrm{bp}$ of complementary sequence) than for rainbow trout sGnRH mRNA (50 bp of complementary sequence with three and one mismatches for sGnRH-I and -II respectively). The antisense RNA was only present in the brain of $\mathrm{AS}(+)$ males and females, whereas sGnRH messengers were also present in $\mathrm{AS}(-)$ fish, and their size (650-700 bp) corresponded to that reported previously (Bailhache et al. 1994, Ashihara et al. 1995). An additional smear band of approximately $900 \mathrm{bp}$ was only detected in $\mathrm{AS}(+)$ fish and could be the sGnRH-antisense transcript. Degradation of the sense/antisense RNA duplex may explain the smear of corresponding bands visualised in this study, as well as the relative decrease in the corresponding endogenous transcripts. However, the same results demonstrated that not all antisense RNA is implicated in 'sense-antisense' interactions, otherwise it would not be possible to detect it due to a rapid degradation of these complexes. Nevertheless, there was more sGnRH mRNA in $\mathrm{AS}(-)$ than in $\mathrm{AS}(+)$ fish, in comparison to $\beta$-actin gene expression, especially in females. This was confirmed by relative RT-PCR analysis that showed a lower level of sGnRH-I mRNA in females (Figs 6 and 10) and sGnRH-II in males (Fig. 10) at the age of 11 months. These results show the specific expression of PabsGnRH-antisense construct in the brain of transgenic trout and its influence on endogenous sGnRH transcripts.

www.endocrinology.org
sGnRH-I and -II mRNA are differently distributed in the brain of rainbow trout. Based on recent data from early vitellogenic females $(\mathrm{GSI}<1 \%)$, sGnRH-I mRNA is predominantly expressed in the olfactory bulbs and telencephalon, whereas sGnRH-II mRNA is the most abundant form in the preoptic area and hypothalamus ( $\mathrm{F}$ Ferrière, unpublished observation). However, in teleosts, projection of sGnRH fibres into the pituitary has been shown to originate from preoptic and hypothalamic neurones (Anglade et al. 1993, Parhar et al. 1998). This is in agreement with the findings of the present study whereby sGnRH-I mRNA was less abundant in the brains of 11-month-old $\mathrm{AS}(+)$ immature females, whereas the sGnRH-II form decreased in maturing $\mathrm{AS}(+)$ males.

\section{Physiological effect of sGnRH-antisense expression}

The comparative physiological characteristics of transgenic and control animals are given in Table 1. Under the experimental breeding conditions of the present study, trout reach maturity at 1 year of age for males and at 2 years for females. In fish brain and pituitary, the GnRH levels remain low in juveniles, increase in adults (Rosenblum et al. 1994) and peak when fish reach maturity. This is the case in the brown trout (Breton et al. 1986), goldfish (Yu et al. 1987) and roach (Breton et al. 1988). In the absence of a hypothalamo-pituitary portal system, sGnRH during this period accumulates mainly in the pituitary, the contents of which are higher than in the brain (Breton et al. 1986, 1988). This indicates an active synthesis of sGnRH prior to maturity. The mechanisms which control sGnRH synthesis are not fully understood. However, in immature rainbow trout, testosterone and estradiol$17 \beta$ induce a rapid and highly significant increase in sGnRH that is much greater in the pituitary than in the brain (Breton \& Sambroni 1996), although there are no sGnRH secretory cells in the pituitary. Due to the anatomical characteristics of the fish hypothalamo-pituitary complex, it has been hypothesised that steroids stimulate $\mathrm{s} \mathrm{GnRH}$ synthesis in brain neurones. sGnRH is not accumulated in sGnRH-producing perikaria but in peptidergic terminals of the neurohypophysis. Thus, an increase in pituitary $\mathrm{sGnRH}$ can reflect $\mathrm{sGnRH}$ synthesis, whereas a decrease in sGnRH pituitary content can be the result either of a decreasing sGnRH synthesis or of sGnRH release from peptidergic endings (Breton \& Sambroni 1996).

In this study, at 11-months, both $\mathrm{AS}(+)$ and $\mathrm{AS}$ (-) females were still immature, whereas nearly all 
males were close to maturity. At 20 months, AS(-) females were undergoing vitellogenesis and $\mathrm{AS}(+)$ varied from immature to mature. This could explain the discrepancy observed in the GnRH content of the brain and pituitary during these two different periods. In immature female goldfish, the sGnRH contents are low both in the brain and the pituitary with a very low rate of sGnRH synthesis (Rosenblum et al. 1994). In 11-month-old immature females (GSI $=0 \cdot 13 \pm 0 \cdot 03$ ) transgene expression did not modify pituitary sGnRH content, but significantly decreased that of the brain. In mature 11-month-old males and 20-month-old females, in which sGnRH synthesis was more active and the release of sGnRH in the pituitary was also activated, the presence of the transgene was accompanied by a significant decrease in the pituitary sGnRH content, which may have accumulated in the gland at that stage. This could be the result of an inhibition of sGnRH synthesis in $\mathrm{AS}(+)$ individuals. This is underlined by the fact that in 11-month-old males the main effect of the transgene expression was a decrease in sGnRH-II transcripts in the brain, which were shown to be the main form synthesised in the area from which the sGnRH projected into the pituitary. In summary, the expression of the transgene in both males and females seems to result in a decrease in pituitary sGnRH content following a possible inhibition of $\mathrm{sGnRH}$ synthesis at stages during which this process is very active.

There was no significant correlation between the decreased level of sGnRH, and either the level of $\mathrm{FSH}$, or of $\mathrm{LH}$ in the blood of both transgenic and nontransgenic fish. The fact that $\mathrm{FSH}$ and $\mathrm{LH}$ levels did not change in $\mathrm{AS}(+)$ fish may signify that the decrease in sGnRH in the pituitary was not great enough to have a direct effect on in vivo secretion of gonadotropins. This could also support the idea of a putative role of $\mathrm{sGnRH}$ expression in the gonads as an additional determining factor of sexual maturation in rainbow trout.

The great variability in maturation levels in $\mathrm{AS}(+)$ females at 20 months of age would tend to suggest the putative role of $\mathrm{sGnRH}$ in the synchronisation of egg development. In addition, the important role of $\mathrm{GnRH}$ as a paracrine regulator of ovarian functions, in particular in the reinitiating of oocyte meiosis, has recently been demonstrated in teleosts (Nabissi et al. 1997, 2000). We observed the expression of $\mathrm{sGnRH}$-antisense mRNA in the gonads of transgenic fish. Thus, the effect of sGnRH-antisense cannot be excluded at the gonadal level; however, the expression of a sGnRHantisense transgene was not sufficient to generate a more pronounced effect on the process of sexual maturation in this line of transgenic trout.

\section{CONCLUSIONS}

The present study has demonstrated that the expression of complementary sGnRH-antisense RNA from the single copy of an integrated transgene driven by a sGnRH promoter from a cognate species may act at the level of sGnRH mRNA and decrease sGnRH levels in the brain and pituitary of transgenic rainbow trout. The induced down-regulation of sGnRH did not decrease FSH or LH concentrations, nor did it induce sterility in transgenic fish. However, some significant disturbances of gametogenesis, which were more pronounced in females, were noticed in the transgenic fish line.

The use of promoter-driven antisense RNA could be a useful approach to inhibit GnRH synthesis in fish. The use of highly appropriate regulatory sequences from the same species, enhancer elements and $100 \%$-matched complement RNA may prove to be absolutely necessary in order to obtain the satisfactory level of $\mathrm{GnRH}$ inhibition.

\section{ACKNOWLEDGEMENTS}

This work was supported by a research grant from the European Community BIO4-CT97-0554. We wish to thank $\mathrm{Mr}$ A. Quémeneur for his help in fish rearing and Marie Hetru for her help in routine experimental manipulations. Many thanks to Dr M A Johnson for editing the English text.

\section{REFERENCES}

Amoros C 1998 Production and analysis of rainbow trout (Oncorhynchus mykiss) transgenic lines expressing the reporter genes under the control of $2.4 \mathrm{~kb}$ promoter-region of salmon chinook (Oncorhynchus tschawytscha) prolactin gene. PhD Thesis. Université de Rennes 1, France.

Anglade I, Zandbergen T \& Kah O 1993 Origin of the pituitary innervation in the goldfish. Cell and Tissue Research 273 345-355.

Ashihara M, Suzuki M, Kubokawa K, Yoshiura, Kobayashi M, Urano A \& Aida K 1995 Two differing precursor genes for the salmon-type gonadotropin-releasing hormone exist in salmonids. Fournal of Molecular Endocrinology 15 1-9.

Bailhache T, Arazam A, Klungland H, Alestrom P, Breton B \& Jego P 1994 Localization of salmon gonadotropin-releasing hormone mRNA and peptide in the brain of Atlantic salmon and rainbow trout. Fournal of Comparative Neurology 15 444-454.

Breton B, Motin A, Billard R, Kah O, Geoffre P \& Precigoux G 1986 Immunoreactive gonadotropin-releasing hormone-like material in the brain and pituitary gland during the peri-ovulatory period in the brown trout (Salmo trutta): relationship with the plasma and pituitary gonadotropin. General and Comparative Endocrinology 61 109-119.

Breton B, Sambroni E \& Gillet C 1988 Gonadotropin releasing hormone $(\mathrm{GNRH})$ and gonadotropin $(\mathrm{GTH})$ variations 
around the spawning period in a wild population of roach (Rutilus rutilus) from Leman lake. I) The female. Aquatic Living Resources 1 93-99.

Breton B, Mikolajczyk T \& Popek W 1992 The neuroendocrine control of the gonadotropin secretion in teleost fish. In Aquaculture: Fundamental and Applied Research, pp 199-225. Eds B Lalhou \& P Vitello. Washington DC: American Geographical Union.

Breton B \& Sambroni E 1996 Steroidal activation of the brain-pituitary complex gonadotropic function in the triploid rainbow trout, Oncorhynchus mykiss. General and Comparative Endocrinology 101 155-164.

Chen TT, Kight K, Lin CM, Powers DA, Hayat M, Chatakondi N, Ramboux AC, Duncan PL \& Dunham RA 1993 Expression and inheritance of RSVLTR-rtGH1 complementary DNA in the transgenic common carp, Cyprinus carpio. Molecular Marine Biology and Biotechnology $288-95$.

Chen TT, Vrolijk NH, Lu JK, Lin CM, Reimschuessel R \& Dunham RA 1996 Transgenic fish and its application in basic and applied research. Biotechnology Annual Review 2 205-236.

Chourrout D, Guyomard R \& Houdebine LM 1986 High efficiency gene transfer in rainbow trout (Salmo gairdneri Richardson), by microinjection into egg cytoplasm. Aquaculture 51 143-150.

Denhardt DT 1992 Mechanism of action of antisense RNA. Sometime inhibition of transcription, processing, transport, or translation. Annals of the New York Academy of Sciences $66070-76$

Devlin RH, Yesaki C, Biagi P, Donaldson EM, Swanson P \& Chan WK 1994 Extraordinary salmon growth. Nature 371 209-210.

Du SJ, Gong ZY, Fletcher GL, Shears MA, King MJ, Idler DR \& Hew CL 1992 Growth enhancement in transgenic Atlantic salmon by the use of an 'all fish' chimeric growth hormone gene construct. Biotechnology $\mathbf{1 0}$ $176-181$.

Erickson RP 1999 Antisense transgenics in animals. Methods: a Companion to Methods in Enzymology 18 304-310.

Estoup A, Largiader CR, Perrot E \& Chourrout D 1996 Rapid one-tube DNA extraction for reliable detection of fish polymorphic markers and transgenes. Molecular Marine Biology and Biotechnology 5 295-298.

Ferriere F, Bailhache T, Mananos Sanchez E, Vacher C, Kah O, Saligaut C \& Jego P 1999 Two different messenger RNAs for salmon gonadotropin releasing hormone (sGnRH) are present in rainbow trout Oncorhynhus mykiss: regulation by gonadal hormones. In Proceedings of the 6th International Symposium of Reproductive Physiology of Fish, p 67. John Grieg: Bergen.

Govoroun M, Chyb J \& Breton B 1998 Immunological cross-reactivity between rainbow trout GTH I and GTH II and their alpha and beta subunits: application to the development of specific radioimmunoassays. General and Comparative Endocrinology 111 28-37.

Hew CL Davies PL \& Fletcher G 1992 Antifreeze protein gene transfer in Atlantic salmon. Molecular Marine Biology and Biotechnology 1 309-317.

Husebye H, Collas P \& Alestrom P 1997 A functional study of the salmon GnRH promoter. Molecular Marine Biology and Biotechnology 6 357-363.

Iyengar A, Muller F \& Maclean N 1996 Regulation and expression of transgenes in fish. Transgenic Research $\mathbf{5}$ 147-166.

Jiang CZ, Kliebenstein D, Ke N \& Rodermel S 1994

Destabilization of rbcS sense transcripts by antisense RNA. Plant Molecular Biology 25 569-576.
Kah O, Zanuy S, Pradelles P, Cerda JL \& Carillo M 1994 An enzyme immunoassay for salmon gonodotropin-releasing hormone and its application to the study of the effect of diet on brain and pituitary GnRH in the sea bass, Dicentrarchus labrax. General and Comparative Endocrinology 95 464-474.

Klungland H, Andersen O \& Aleström P 1992a The salmon $\mathrm{GnRH}$ encoding gene in salmonids. Molecular Marine Biology and Biotechnology 1 420-425.

Klungland H, Lorens JB, Andersen O, Kisen GO \& Alestrom P $1992 b$ The Atlantic salmon prepro-gonadotropin releasing hormone gene and mRNA. Molecular and Cellular Endocrinology 84 167-174.

Kottler ML, Starzec A, Carre MC, Lagarde JP, Martin A \& Counis R 1997 The genes for gonadotropin-releasing hormone and its receptor are expressed in human breast with fibrocystic disease and cancer. International Fournal of Cancer 71 595-599.

Le Bail PY, Fostier A \& Marcuzzi O 1983 Limites et amelioration du sexage des salmonidés par dosage de la 11 -cetotestosterone. Canadian Fournal of Zoology 61 457-460.

Maclean N 1998 Regulation and exploitation of transgenes in fish. Mutation Research 399 255-266.

Maier CC, Marchetti B, Le Boeuf RD \& Blalock JE 1992 Thymocytes express a mRNA that is identical to hypothalamic luteinizing hormone-releasing hormone mRNA. Cellular and Molecular NeuroBiology 12 447454.

Martinez R, Estrada MP, Berlanga J, Guillen I, Hernandez O, Cabrera E, Pimentel R, Morales R, Herrera F, Morales A, Pina JC, Abad Z, Sanchez V, Melamed P, Leonart R \& de la Fuente J 1996 Growth enhancement in transgenic tilapia by ectopic expression of tilapia growth hormone. Molecular Marine Biology and Biotechnology 5 62-70.

Mason AJ, Hayflick JS, Zoeller RT, Young WS, Phillips HS, Nikolics K \& Seeburg PH 1986 A deletion truncating the gonadotropin-releasing hormone gene is responsible for hypogonadism in the hpg mouse. Science 234 1366-1371.

Matsumoto K, Kakidani H, Takahashi A, Nakagata N, Anzai M, Matsuzaki Y, Takahashi Y, Miyata K, Utsumi K \& Iritani A 1993 Growth retardation in rats whose growth hormone gene expression was suppressed by antisense RNA transgene. Molecular Reproduction and Development 36 $53-58$.

Matsumoto K, Kakidani H, Anzai M, Nakagata N, Takahashi A, Takahashi Y \& Miyata K 1995 Evaluation of an antisense RNA transgene for inhibiting hormone gene expression in transgenic rats. Developmental Genetics 16 $273-277$.

Mori T \& Devlin RH 1999 Transgene and host growth hormone gene expression in pituitary and nonpituitary tissues of normal and growth hormone transgenic salmon. Molecular and Cellular Endocrinology 149 129-139.

Munir MI, Rossiter BJ \& Caskey CT 1990 Antisense RNA production in transgenic mice. Somatic Cell and Molecular Genetics 16 383-394.

Nabissi M, Pati D, Polzonett-Magni AM \& Habibi HR 1997 Presence and activity of compounds with sGnRH-like activity in the ovary of seabream (Sparus aurata). American Fournal of Physiology 272 111-117.

Nabissi M, Soverchia L, Polzonett-Magni AM \& Habibi HR 2000 Differential splicing of three gonadotropin-releasing hormone transcripts in the ovary of seabream (Sparus aurata). Biology of Reproduction 62 1329-1334.

Okayama H \& Berg PA 1992 cDNA cloning vector that permits expression of cDNA inserts in mammalian cells. Biotechnology 24 270-279.

Parhar IS, Iwata M, Pfaff DW \& Schwanzel-Fukuda M 1995 Embryonic development of gonadotropin-releasing hormone 
neurons in the sockeye salmon. Fournal of Comparative Neurology 362 256-270.

Parhar IS, Soga T, Ishikawa Y, Nagahama Y \& Sakuma Y 1998 Neurons synthesizing gonadotropin-releasing hormone mRNA subtypes have multiple developmental origins in the medaka. Fournal of Comparative Neurology 401 217-226.

Pitkanen TI, Krasnov A, Teerijoki H \& Molsa H 1999 Transfer of growth hormone (GH) transgenes into Arctic charr (Salvelinus alpinus L.) I. Growth response to various GH constructs. Genetic Analysis 15 91-98.

Rosenblum PM, Goos HJ \& Peter RE 1994 Regional distribution and in vitro secretion of salmon and chicken-II gonadotropin-releasing hormones from the brain and pituitary of juvenile and adult goldfish. General and Comparative Endocrinology 93 369-379.

Scherczinger CA, Yates AA \& Knecht DA 1992 Variables affecting antisense RNA inhibition of gene expression. Annals of the New York Academy of Sciences 660 45-56.

Singh J, O’Neill C \& Handelsman DJ 1995 Induction of spermatogenesis by androgens in gonadotropin-deficient (hpg) mice. Endocrinology 136 5311-5321.

Sokol DL \& Murray JD 1996 Antisense and ribozyme constructs in transgenic animals. Transgenic Research $\mathbf{5}$ 363-371.

Tewari R, Vanhee M, Perrot E \& Chourrout D 1992 Mendelian transmission, structure and expression of transgenes following their injection into the cytoplasm of trout eggs. Transgenic Research 1 250-260.

Upadhyay SN 1977 Morphologie des gonades immatures et étude expérimentale de l'induction de la gamétogénèse chez la truite arc-en-ciel (Salmo gairdnerii R.). Thèse doctorat d'état es sciences naturelles. Université Pierre et Marie Curie, Paris VI.

Von Schalburg KR \& Sherwood N 1999 Regulation and expression of gonadotropin-releasing hormone gene differ in brain and gonads in rainbow trout. Endocrinology 140 3012-3024.

Von Schalburg KR, Harrower WL \& Sherwood N $1999 a$ Regulation and expression of gonadotropin-releasing hormone in salmon embryo and gonad. Molecular and Cellular Endocrinology 157 41-54.

Von Schalburg KR, Warby CM \& Sherwood N $1999 b$ Evidence for gonadotropin-releasing hormone peptides in ovary and testis of rainbow trout. Biology of Reproduction 60 1338-1344.

Wang R, Zhang P, Gong Z \& Hew CL 1995 Expression of the antifreeze protein gene in transgenic goldfish (Carassius auratus) and its implication in cold adaptation. Molecular Marine Biology and Biotechnology 4 20-26.

White RB \& Fernald RD 1998 Genomic structure and expression sites of three gonadotropin-releasing hormone genes in one species. General and Comparative Endocrinology 112 17-25.

Yu KL, Nahorniak CS, Peter RE, Corrigan A, Rivier JE \& Vale WW 1987 Brain distribution of radio-immunoassayable gonadotropin-releasing hormone in female goldfish: seasonal variation and periovulatory changes. General and Comparative Endocrinology 67 234-246.

REVISED MANUSCRIPT RECEIVED 30 August 2000 